Historic, Archive Document

Do not assume content reflects current scientific knowledge, policies, or practices. 



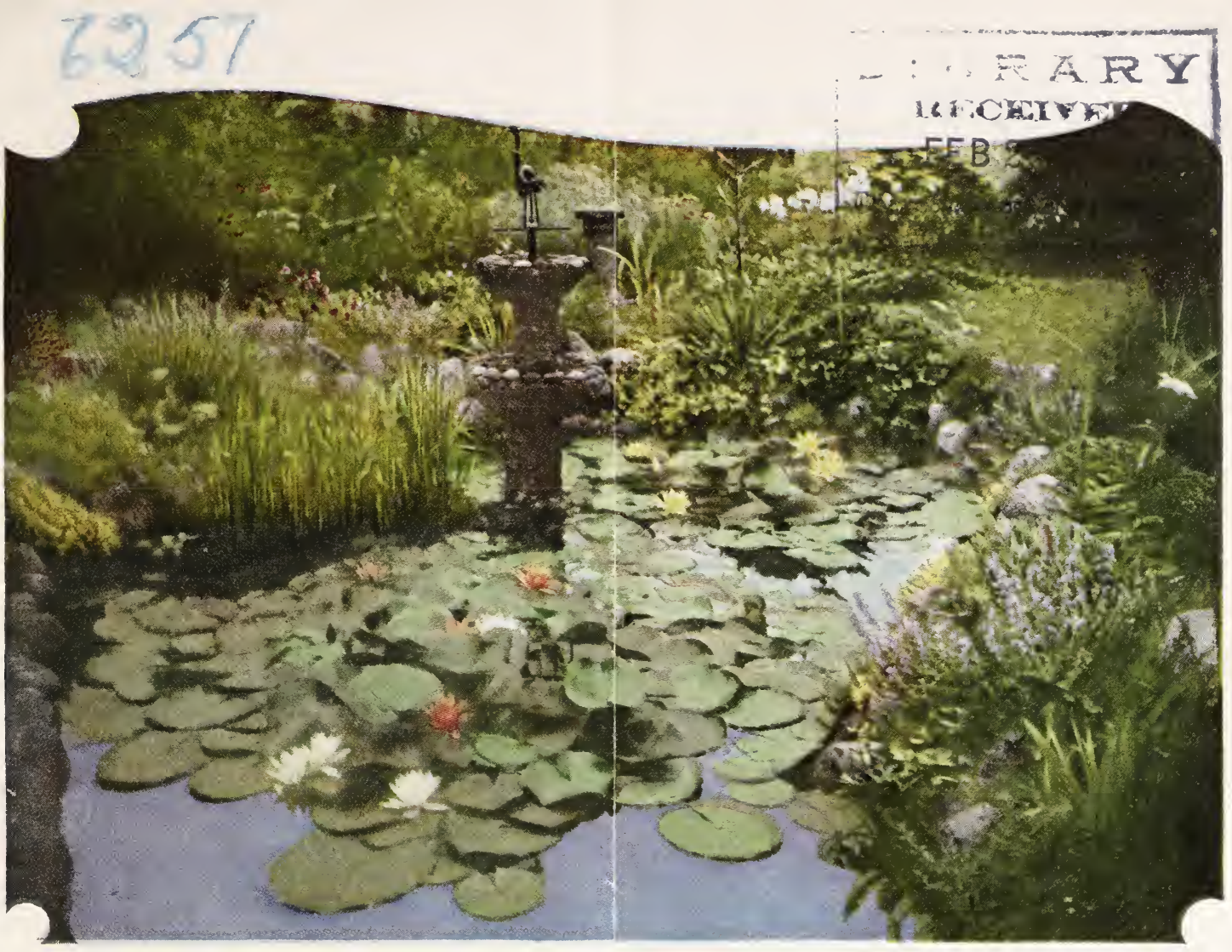

\section{Bring New Beauty To YOUR GARDEN}

\section{PRICES}

on large quantities of all plants included in this catalog will be given on request. Write us.

The larger the quantity the lower the price.

Issued by

\section{New Market Perennial Gardens NEW MARKET, New Jersey}

Office and Nurseries at Randolphville Road, New Market, New Jersey 


\section{Just a Few Words to Our Friends and Customers}

It is in sincere appreciation of your patronage that we present you with our new catalog.

During the past few years we have enjoyed a continuous annual increase in business, and now find it advisable and possible to publish a larger and more complete catalog for your convenience.

This new catalog tells you all about our wonderful selection of Hardy Perennials, as well as Ever. greens, Roses and Flowering Shrubs.

Our prices as you will note are very low on the plants we offer, in fact some are almost reduced to half the regular price. This we have done or have been able to do on account of increased production. Several million hardy plants are grown in our nurseries annually, and we find a ready sale for them.

Give us a trial order and be convinced. Our prices are postpaid, only add $15 \mathrm{c}$ for packing and insurance on orders up to $\$ 3.00$, from $\$ 3.00$ to $\$ 5.00$ add $30 \mathrm{c}$, from $\$ 5.00$ to $\$ 10.00$ we do not charge for packing and insurance.

We guarantee our plants to be true to name, and in good condition when received. We cannot be responsible for growing losses over which we have no control.

TERMS OF SALE. Our terms are cash with order in form of money order, or your personal check. No C. O. D.'s are shipped unless $50 \%$ of the amount is enclosed with the order.

In ordering PLEASE PRINT full name, number of house and name of Street, Town or State in which you live, and if possible the County.

Any order, whether large or small, will have our very best attention.

Our shipping season starts in the fall from September 1st until December 15th. In the spring from April 1st until June 15th.

Early orders will be appreciated by us, and more satisfactory for you.

Sincerely yours,

AUG. S. HOFFER, Manager.

\section{New Market Perennial Gardens}

Randolphville Road

New Market, New Jersey

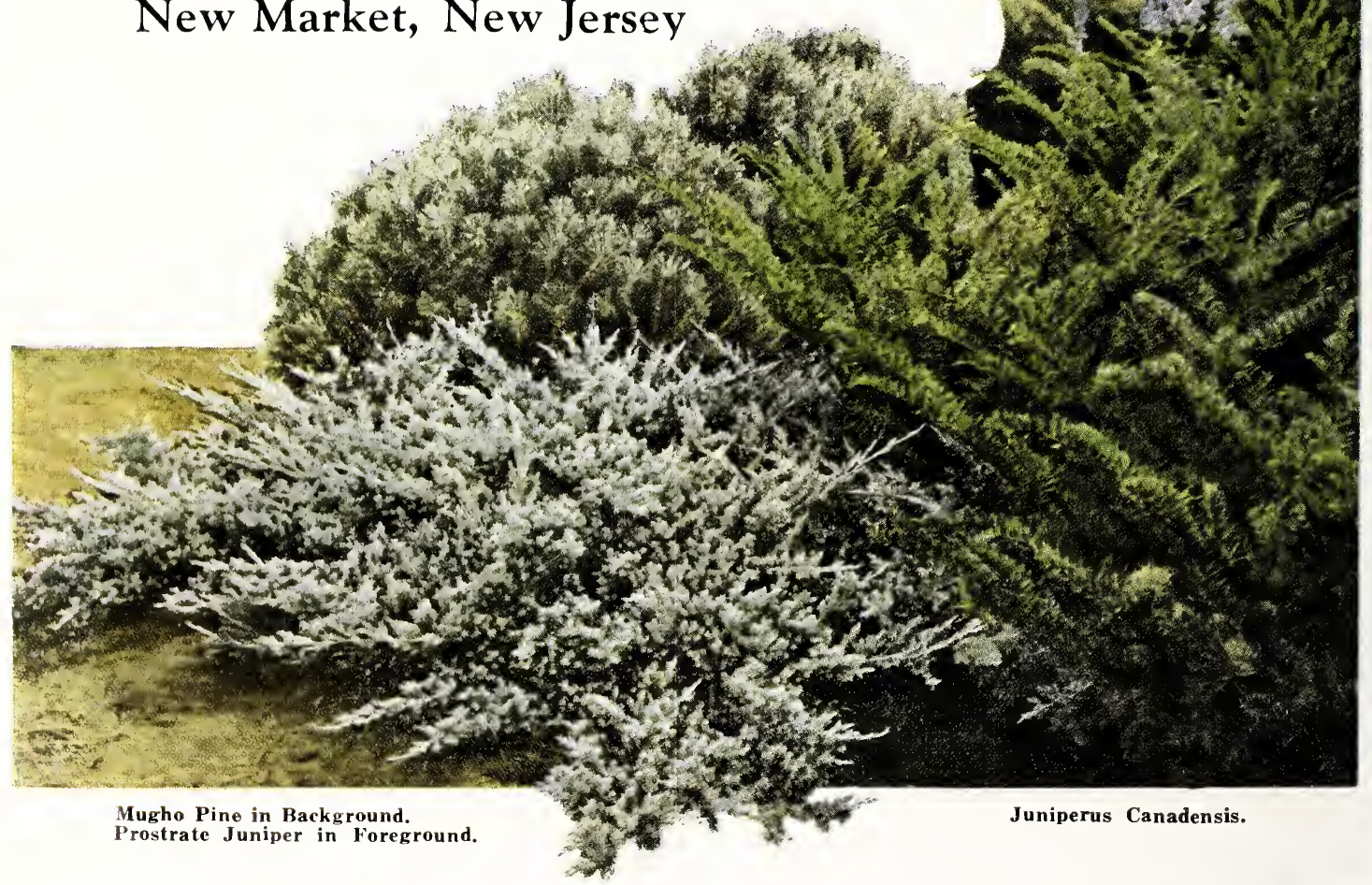




\section{Evergreens}

Our Special Consisting of 2 Arbor-Vitae, 2 Norway Fir 2 Juniperus Communis. These trees are 5 to 7 years old and once or twice transplanted. This group of trees, within 2 year's will 1 epresent a value of $\$ 15.00$ or more. HERE IS A REAL BARGAIN-8 EVERGREENS FOR ONLY

ARBOR-VITAE, American,

1 to $11 \% \mathrm{ft}$, nicely shaped. Each $\ldots \ldots \ldots \ldots \ldots \ldots \ldots \$ \ldots$

$11 \frac{2}{2}$ to $2 \mathrm{ft}$. Each

A., Chinese.

1 to $11 / 2 \mathrm{ft} .2$ for

$11 \frac{2}{2}$ to $2 \mathrm{ft}$. Each

A., Globe. Large and well shaped.

6-year-old. Each

CEDRUS deodara. God Tree of the Himalayas. Feathery, artistic blue foliage: considered the most beautiful ornamental evergreen.

1 to $1 \frac{11 / 2}{\mathrm{ft}}$. Each

$11 / 2$ to $2 \mathrm{ft}$. Each

JUNIPERUS communis. Spreading.

5-year old. 2 for

J., Irish.

1 to $1 \frac{1}{2} \mathrm{ft}$. Each

Pfitzeriana. This remarkable tree is one of the most important evergreens today. It will grow in any location.

5-year-old plants. Each

PINE, Mugho. For growing and spreading. 4-year-old, once transplanted. "2 for 6-year-old, twice transplanted. Each

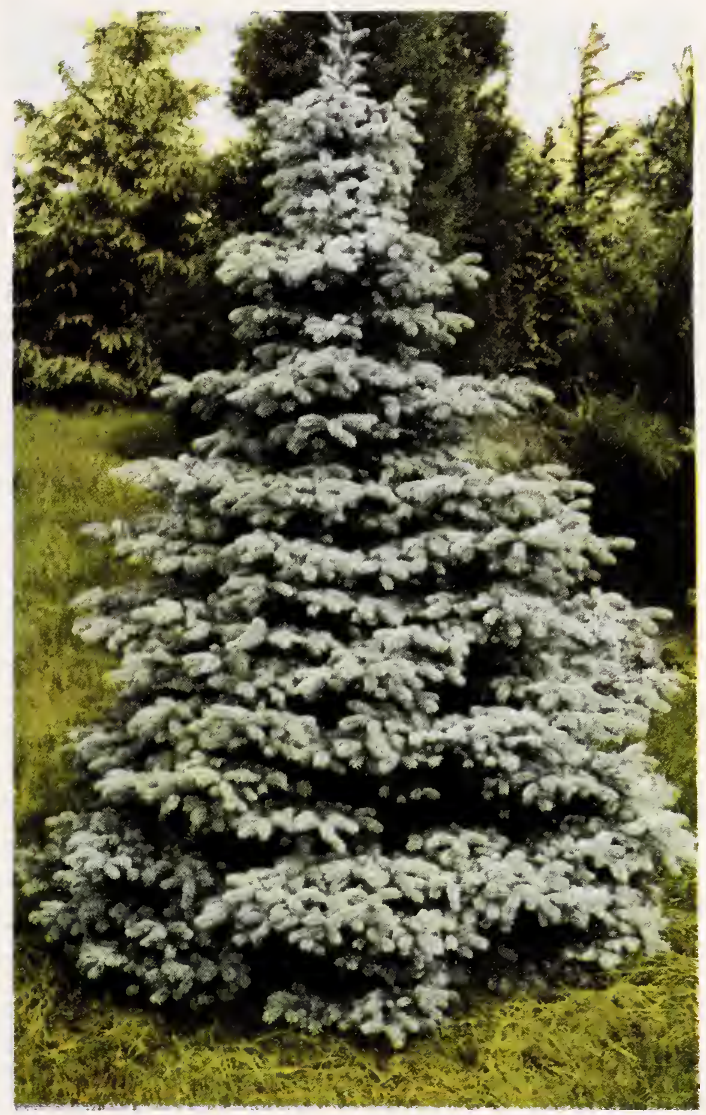

SPRUCE, Colorado Blue. King of the evergreen

4 -year-ald trees. 2 for

7 -year-old trees. Each

Larger size, over 1 foot. Per foot

S., Norway.

1 to $1 \frac{1}{2} \mathrm{ft} .2$ for

11,2 to $2 \mathrm{ft}$. Each

Colorado Blue Spruce.

RHODODENDRON maximum, Pink.

R. catawbiense. Red.

R. carolinianum. Dark pink.

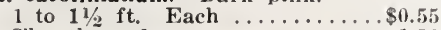

The three for

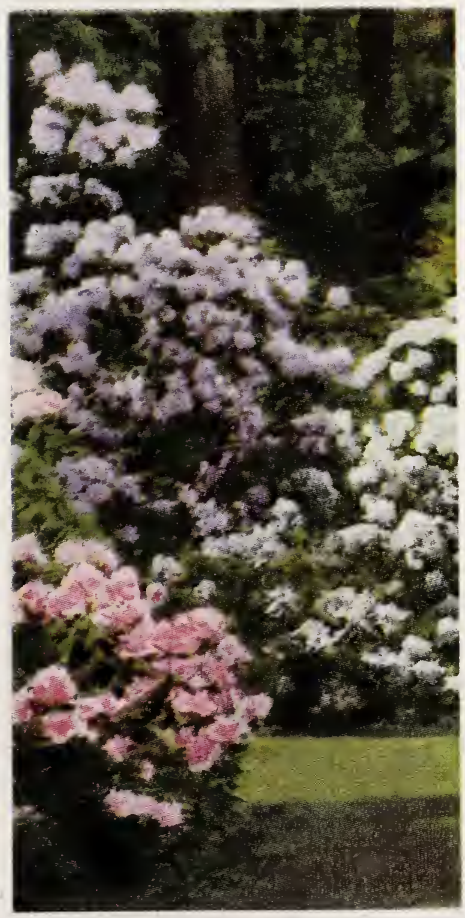

Rhododendrons.

\section{Hardy Shrubs}

ALTHEA (Rose of Sharon or Hibiscus). Upright growing shrub producing large flowers in August and September. The flower's resemble the blooms of Hollyhocks. Dark red, white and pink.

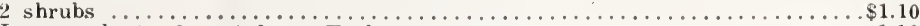

Larger plants, 3 to 4 feet. Each.

AZALEA nudiflora. A handsome early-flowering species. Perfectly hardy. Deep pink flowers.

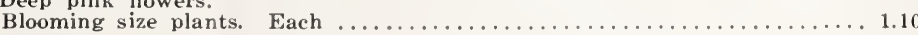

A. mollis. One of the most beautiful and hardy of the Azaleas. Deep orange flowers. Very large.

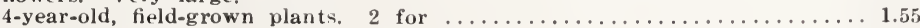

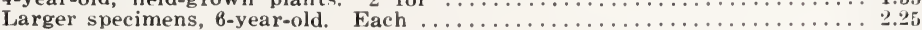

BARBERRY, Japanese. One of our most useful shrubs, it can be used for fences, beds, or as a hedge. It has no equal.

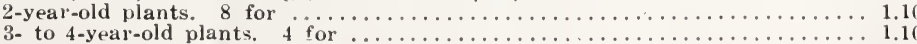

BUTTERFLY BUSH (Summer Lilac). A beautiful shrub that blooms all summer. Perfectly hardy.

FORSYTHIA (Golden Bell), Early-floweling: yellow bloom before the leaves come out

2 shrubs for.

HONEYSUCKLE, PINK BUSH. A lovely shrub with pink flowors in early spring.

HYDRANGEA paniculata. White, changing to vink and purple in the fall.

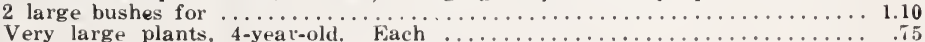

Very large plants, 4 -yeat-old. Fach $\ldots \ldots \ldots \ldots$
The New Hardy (Nikko Blue), A true sky-blue.

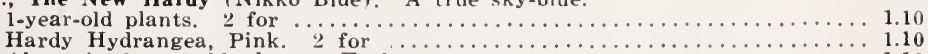

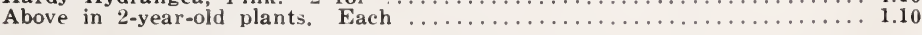

MAGNOLIA TREE. Pink and White.

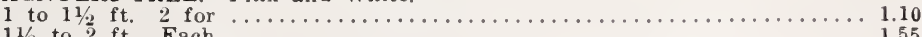


MOCK ORANGE (Syringa). White; very fragrant.

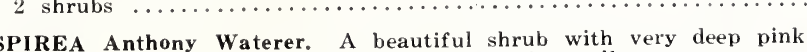

PIREA Anthony Waterer. A beautiful shrub with

flowers from June to October.
2-year-old bushes. 2 for ....

S. Van Houttei (Bridal Wreath). White.

2 -year-old bushes. 2 for

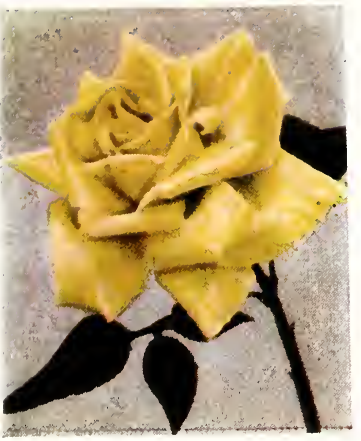

Hybrid Tea Rose.
1.10

\section{Roses}

HYBRID TEA ROSES. The queen of flowers. In growqueen of flowers. In growsome of the hardiest and most free blooming varieties that are in the market today, and offer them to you in several shades of yellow, pink, red and white.

2-year-old, field-grown.

2 bushes for .......\$1.10

12 bushes for ........6.00

HARDY CLIMBING ROSES. In any color you desire. 2-year-old, field-grown.

2 bushes for $\ldots \ldots \ldots \ldots \$ 1.10$

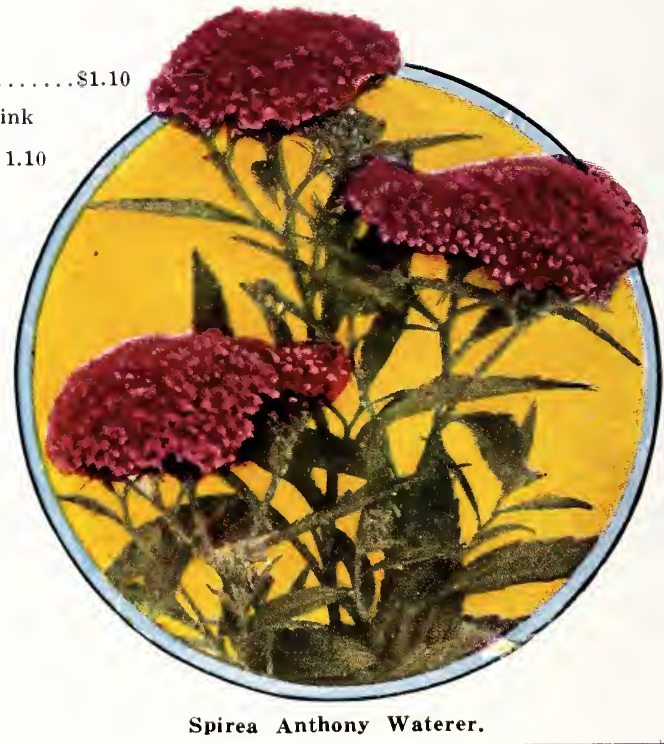

Spirea Anthony Waterer.

\section{Hardy Perennial Plants}

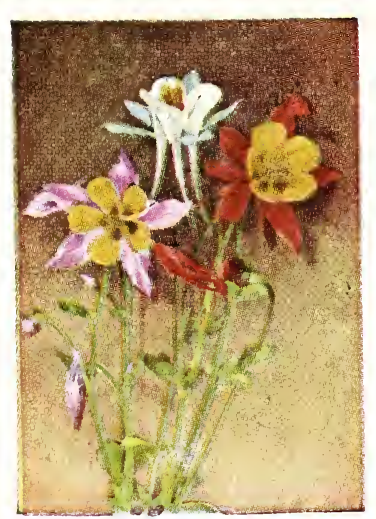

Aquilegia-Columbine.

Plants which live year after year in the garden are known as perennials. They include some of the old-fashioned flowers such as Phlox, Larkspur, Columbines, Foxglove and Canterbury Bells. It is a compliment to a flower to call it old-fashioned, for it indicates that the flower was popular with our grandparents, and was so worth while that we grow that the flower was popular with our grandparents, and was so worth while that we grow
them even today. Each nationality coming to our shores has brought with them the old favorites of the ancestral home.

Someone has has truly written that "The most beautiful gardens are in the mind, not in the soil." The flowers in your own garden are always more interesting than those in the gardens of others. They are the results of your labor; there is the enjoyment of ownership; they are your flowers.

The progressive garden lover should each year add some of the best kinds of plants to his garden. The cost is so small when you compare it with the joy and pleasure that you have every year, from a few cents or dollars spent on some of these lovely hardy plants. If you have in mind making a perennial garden, or borders, or a rock garden, and would like to have some advice, do not hesitate to write to us, together with a little sketch of your lot, and we shall help you all we possibly can. We offer you here a selection of hardy plants for you to choose from. All one-year-old, cold frame-grown plants, that will bloom the first year. They are all once transplanted with a good root system, which will surely make you successful if a little care is given. To induce you to buy, we have made our prices very low, and the same price all the way through. Take your pick from the list, not less than 2 of a variety at this remarkably low price of

\section{\$1.75 Per Dozen, Postpaid}

NOTE. We have the same varieties in 2-year-old, field-grown clumps that we offer you for $\$ 3.00$ per dozen clumps, your choice.

You are cordially invited to visit our nurseries if you can, and make your selection; if not, order by mail, and we will surely do all we can to make you one of our many satisfied

ACHILLEA ptarmica, "The Pearl." One of the best hardy, white perennials. Grows about 2 feet high, and from spring to frost is covered with heads of purst white, double flowers.

ACONITUM napellus. Produces lon? spikes of blue and white flowers. Well adapted for planting among shrubbery $01^{\circ}$ in shady corners.

ACANTHUS latifolius. Large, decorative plant for single specimen. 4 plants, \$1.10. AGROSTEMMA. Strong, ereet growing plants with silvery foliage, which contrasts well with the showy flowers, which ale produced during June and July.

A. coronaria (Mullein Pink). Bright rosy crimson. $21 \%$ to 3 feet.

ADONIS vernalis. Large, yellow flowers, good for the border. 2 feet.

ALYSSUM saxatile compactum. An indispensable plant for the rockery or border, growing 1 foot high and producing in May, masses of broad, flat heads of bright yellow flowers.

ANCHUSA. One of the best hardy perennials, and becoming more popular each season. Grows 3 to 5 feet high and bears in abundance flowers of the richest gentian blue during May and June.

ANEMONE (Japanese Windflower). A very pleasing perennial, producing large flowers; few plants compare with them in beauty: fine for bouquets.

A. coronaria (Poppy Anemone). Mixed colors.
ANEMONE, St. Brigid. A beautiful selection of the above. Our seed comes from a famous Irish grower and comprises semi-double and double flowers in a wonderful array of colors.

ANTHEMIS (Hardy Marguerite). A most satisfactory hardy perennial, bearing all summer, daisy-like, golden yellow blossoms: excellent for cutting. 2 feet. AQUILEGIA (Columbine). Our LongSpurred Columbines. This strain is unquestionably the finest yet produced. The plants are of strong, thrifty growth with flowers of largest size, varying in color through charming tones of cream. pink, lavender, blue, white, red, etc.

ARABIS alpina. One of the earliest and prettiest spring flowers. The spreadin? tufts are covered with a sheet of pu:e white flowers as soon as the snow disappears. Unequalled for rockeries o. edging, withstanding the drought, and is always neat. 6 inches.

ARMERIA formosa. Heads of rosy pink flowers, useful for edging or rockery. Bloom in May and June.

ASTER, PEREN I A L (Michaelmas Daisy). Mixed. Saved from a splendid collection. Good for rock garden. Bloom freely during September and October.

AUBRIETIA, Large-Flowering Hybrids. A beautiful dwarf rock plant, covered with sheets of bright flowers in spring and early summer. customers, ORDER TODAY.

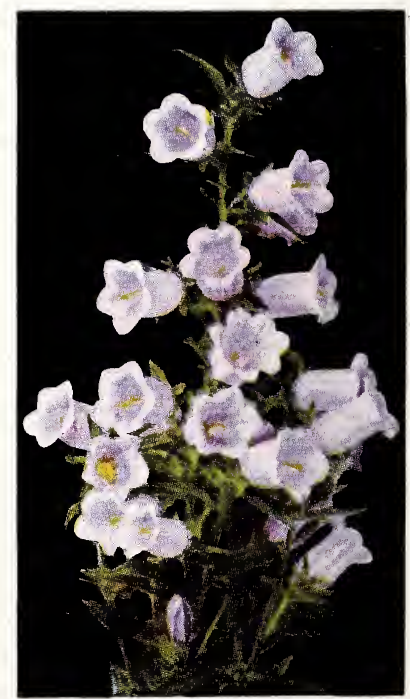

Canterbury Bells. 
AURICULA (English Primrose). A well known favorite of great beauty. Seed saved from splendid choice mixed varieties. Hardy perennials. 6 inches. Bloom all summer. BELLIS perennis (Double Daisy). Finest double mixed, best quality obtainable. Good for rock garden.

BOCCONIA cordata (Plume Poppy or Tree Celandine). Eifective, hardy perennial for single specimens or groups on lawn Foliage glaucous green; bears freely, spikes 2 to 3 feet long, of cream colored flowers. 6 to 8 feet.

CAMPANULA (Bellflower). Well known, beautiful, hardy herbaceous perennials, bearing a

C. carpatica (Carpathian Harebell). Blue. In bloom the whole season, color clear blue; grows 6 inches high, especially good for edging and rockery.

carpatica alba. The white-fowered form of the abouted of the hardy Bellflowers; grows 2 to 3 feet high, with large, blue flowers.

C. medium (Canterbury Bells).

C medium calycanthema (Cup and Saucer Canterbuı Bells). Dark blue, light blue, lavender, rose-pink, white, and mixed.

CENTAUREA montana (Perennial Cornflower). Grows 2 feet high, bearing large, violet-blue flowers from July to September. Excellent for cutting.

CERASTIUM tomentosum (Snow-in-Summer). A desirable, low-growing plant with silvery

foliage and white flowers in June. Suitable for the rockery, or for carpeting dry,
spots or for covering graves; can also be used with good effect in carpet bedding.

CHRYSANTHEMUM maximum (Shasta Daisy). There is always a good demand for these

C. maximum, Alaska. The largest and best of the Shasta Daisies.

C. Hardy Exhibition. Our wonderful selection, flowers measure 6 to 8 inches across; in color

of pink, bronze, yellow and white. 8 plants for $\$ 1.10$.

C., Pompon. In the same colors as above. 8 plants for $\$ 1.10$.

COREOPSIS (Golden Coreopsis). One of the most popular golden yellow perennials.

C. lanceolata grandiflora. An extra fine strain of this useful golden yellow hardy perennial

C. lanceolata grandiflora f. pl. (Double-Flowering Coreopsis). This new double and semidouble form is just as easy to grow as the single, and the extra petalage adds a further charm to the flower. Bloom all summer.

DICTAMNUS fraxinella alba (Gas Plant). A very showy, hardy perennial, forming a bush about $21 \%$ feet in height, having fragrant foliage and spikes of pure white flowers during June and July.

DELPHINIUM (Hardy Larkspur). The Delphiniums are one of the most popular perennials,

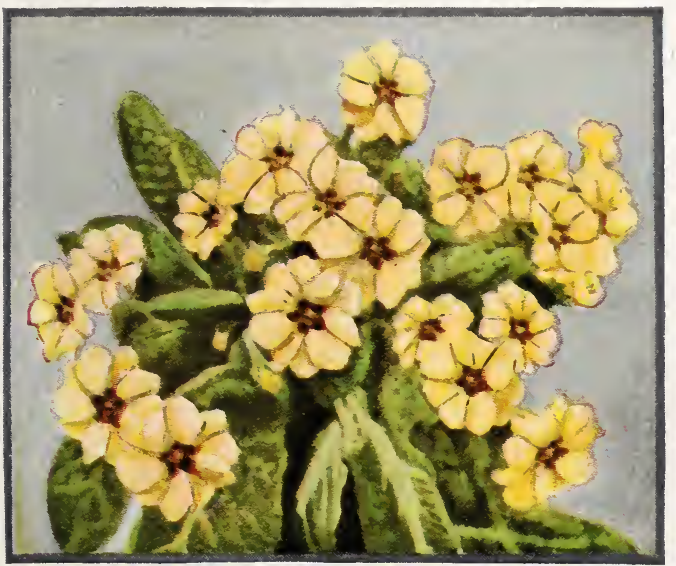
and are in great demand both for garden decoration and for blue form of strong, vigorous size of brilliant iridescent turquoise blue.

D. belladonna, Improved. A very select belladonna light blue, free and continuous bloomer throughout the whole summer o. cardinalis.

Delphinium, something new a mong Del.

DICENTRA spectabilis (Bleeding Heart). The old-fashioned flower of grandmother's garden. 2-year-old, f
plants. 2 for $\$ 1.10$.

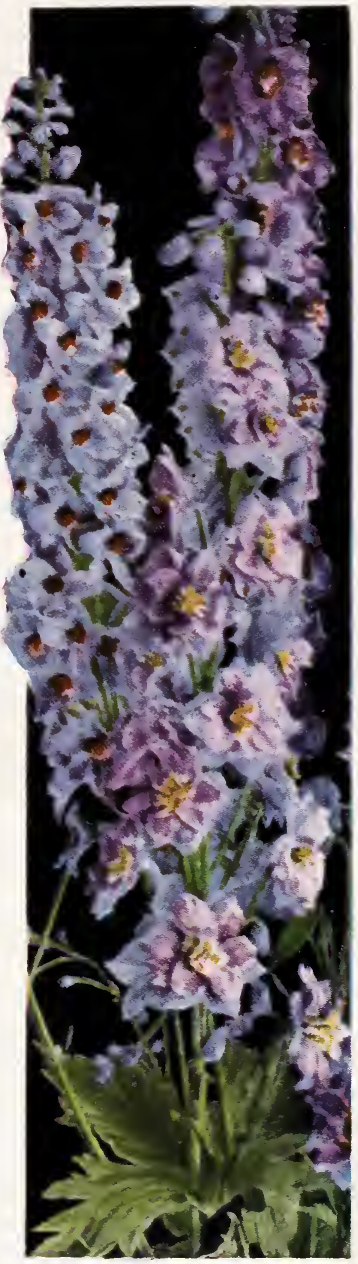

Hybrid Delphinium.

DIGITALIS (Foxglove). The

Foxgloves must be included in all collections of hardy plants Very popular for planting among shrubbery and semi-shady

D., Giant Shirley. A greatly improved strain of unusually strong. igorous growth and producing spikes of enormous bloom

English Primrose.

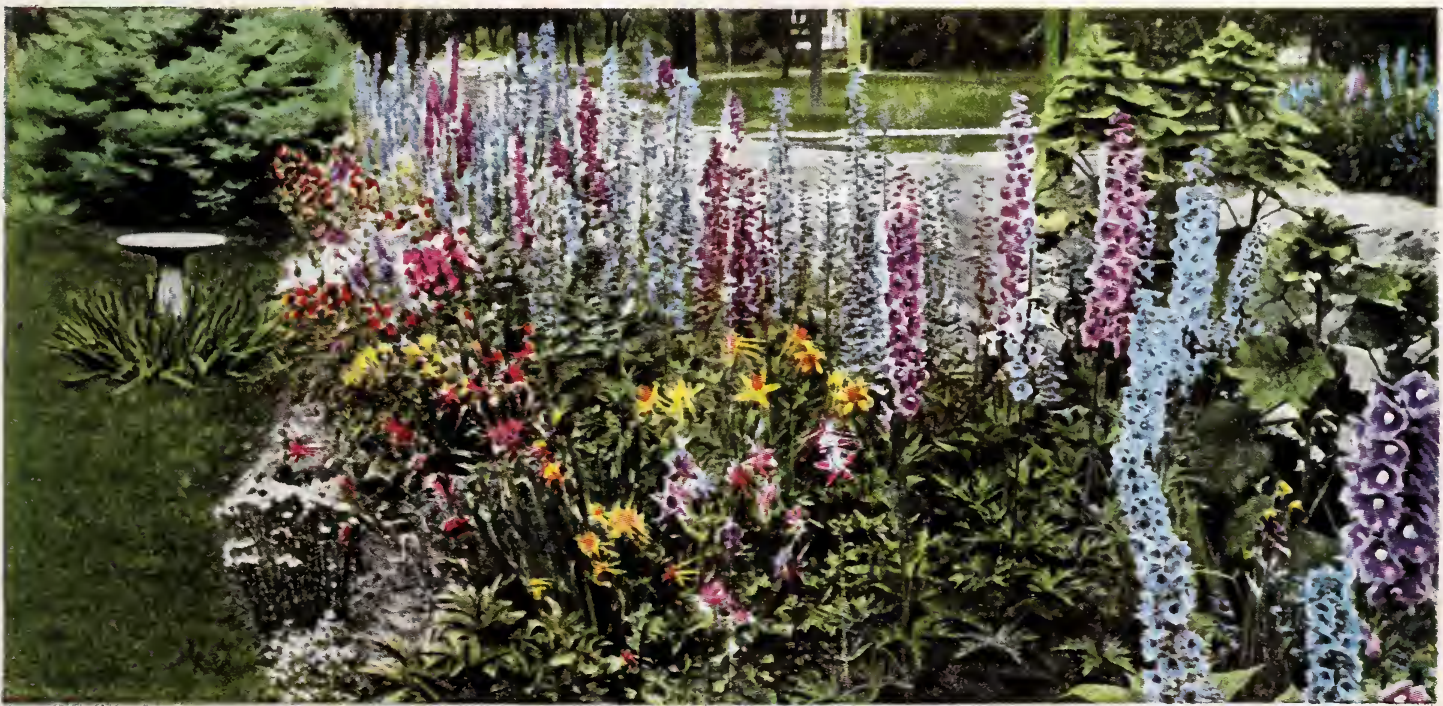

The Effective Use of Delphiniums as a Background for the Perennial Planting. 


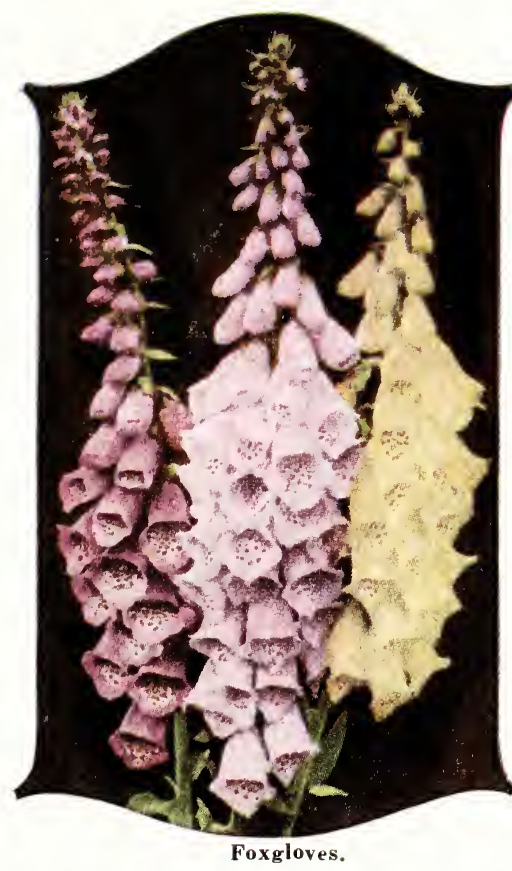

HARDY PERENNIALS-Continued.

DIGITALIS gloxiniaeflora. Purple, rose, white and mixed, all colors,

D. grandiflora. Light yellow.

D. maculata superba. Fine spotted strain.

EUPATORIUM (Hardy Ageratum). From August until November the plant is covered with dense heads of white flowers. 2 feet.

ECHINOPS ritro (Globe Thistle). Striking hardy perennial plants with handsome silvery, thistle-like foliage and fine steel-blue flowers in round heads, which can be used for cutting. 3 to 5 feet. 4 plants for $\$ 1.10$.

ERYNGIUM amethystinum (Sea Holly). Steel-blue flowers. 3 feet.

GEUM atrosanguineum fl. pl. (Avens). Beautiful hardy perennials, bearing profusely, large, showy, dark crimson, double flowers, all through the summer; an elegant flower for bouquets.

G., Mrs. Bradshaw. Large, double, brilliant orange-scarlet flowers throughout the entire summer.

G., Lady Stratheden. Large, double flowers of rich golden yellow, and grows about $1 \frac{1}{2}$ feet.

GENTIANA (Blue Gentian). Bears flowers of intense deep blue from July until October. Grows well in the shade. 2 feet.

GYPSOPHILA (Baby's Breath). The following are always in demand to mix with other cut flowers.

G. paniculata fl. pl. Double flowering. The original type and one of the best perennials in the list for cutting.

GAILLARDIA (Blanket Flower). 'The following are among the showiest and most effective hardy perennial plants, and should find a place in every hardy border: also splendid for cutting.

G. grandiflora compacta. A compact variety forming bushy plants 12 to 15 inches high, and bearing long-stemmed flowers well above the foliage.

G. grandiflora kermesina splendens. Rich crimson, narrow, canary-yellow border.

G. grandiflora, Copper-Red. A striking color in this popular perennial.

G. grandiflora, Super Mixed. Our own savings : splendid combination of crimson and gold in

G., Portola Hybrids. We consider this one of the most valuable perennial introductions in many
upright habit of growth, 21 to 3 feet high. years. The plant is of strong, vigorous, upright habit of growth, $21 / 2$ to 3 feet high;
with heavy, leathery, glaucous foliage. The long flower stems, straight and strong, hold with heavy, leathery, glaucous foliage. T T

HELENIUM (Sneezewort). Strong growing, hardy perennial, giving an enormous crop of flowers in late summer.

H. autumnale superbum. Goiden yellow flowers, 5 to 6 feet.

H., Riverton Beauty. Rich lemon-yellow with a large, purplish black cone. 4 feet.

HELIANTHEMUM mutabile (Rock or Sun Rose). Exceedingly pretty low growing evergreen plant forming broad clumps, and which during their flowering season, July to September, are quite hidden by a mass of bloom well adapted for the front of the border, the rockery, or a dry, sunny bank. Choice mixed varieties.

helianthuS (Hardy Perennial Sunflower).

Mixed. Contains the finest single-flowering

hardy perennial sorts. As subjects for the

hardy border as well as for cutting, thev are of great value.

HELIOPSIS Pitcheriana (Orange Sunflower). A desirable hardy plant 3 to 4 feet high. Flowers are of a beautiful deep golden yellow color about 2 inches in diameter, of very thick texture and very graceful for cutting.

HEUCHERA (Coralbells). A beautiful plant with slender spikes of soft coral-pink, bellshaped flowers from May until July. Good for cutting, for rockery and shady positions. 18 inches.

GIANT HIBISCUS. A wonderful improved form of our native Marshmallow, in which flowers of enormous size frequently 10 to 12 inches in diameter, have been developed The colorings comprise rich dark red, soft mallow-pink and pure white. The plant grows from 5 to 8 feet high, and is very floriferous, blooming from early in June until late autumn, and is perfectly hardy.

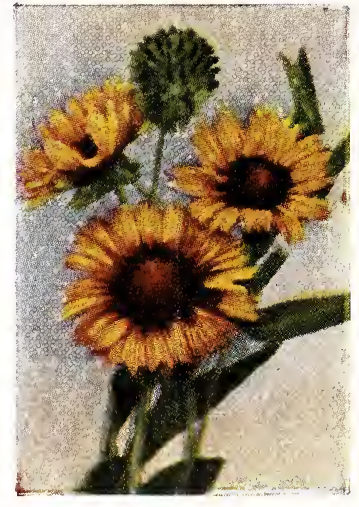

Gaillardia-Blanket Flower.

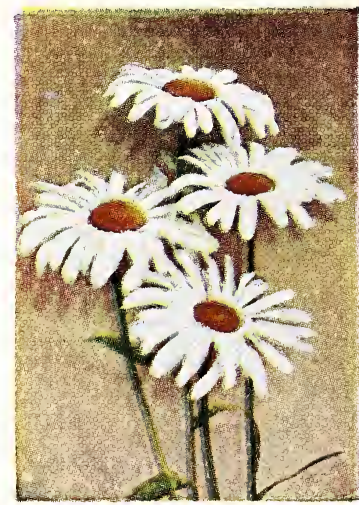

Shasta Daisy.

HOILYHOCKS. Double Newport Pink. A charming shade of pure pink, double Pink Perfection, rich rose-pink, bright rose, red, maroon, salmon-rose, white, and yellow.

IBERIS (Hardy Candytuft). Gibraltarica hybrida. White shading to lilac.

I. sempervirens. The popular hardy white variety. Good for rockery.

LATHYRUS (Evellasting or Hardy Sweet Pea). Showy, free-flowering, hardy perennial climbers for covering old stumps, fences, etc. Continually in bloom; fine for cutting; mixed colors.

LAVANDULA (Sweet Lavender). This is the true old-fashioned Sweet Lavender with fragrant, blue flower's which bloom from July until August. 18 inches.

LIATRIS (Blazing Star or Gay Feather). Most showy and attractive hardy perennial plants, with long spikes of purple and rosy purple flowers from. July to September. 5 feet. Mixed varieties.

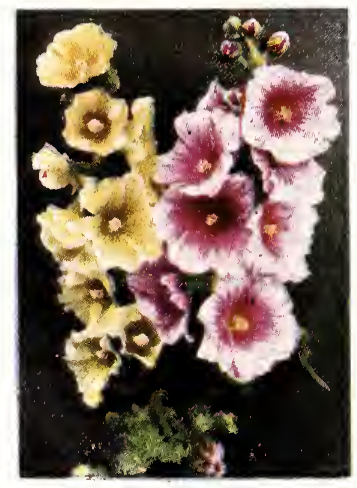

Hollyhocks.
LINUM perenne (Flax) A desirable plant for the border or peckent foliage and large, blue flowers all summer.

LOBELIA cardinalis. Rich, fiery cardinal flower's in dense spikes during August and September. $2 \frac{1}{2}$ feet.

LUPINUS polyphyllus (Lupine). Effective plants, producing large spikes of flowers blooming in May and June. They require only well prepared garden soil, preferably in a semi-shady location. 3 feet.

LYCHNIS (Rose Campion; Jerusalem Cross). Handsome, hardy perennial plants of easy culture.

L. Arkwrighti. A beautiful hybrid of L. chalcedonica and L. Haageana, producing brilliantly colored flowers in crimson and scarlet to salmon and other shades. Bloom freely from June to September. 3 feet.

LYTHRUM roseum superbum (Loosestrife). A very pretty hardy perennial; grow's about 3 to 4 feet high, and produces spikes of rosy flowers from July to September.

OENOTHERA (Evening Primrose). A very attractive plant that grows either in sunlight or shade. Covered with large golden yellow flower's from June until September. About 2 feet.

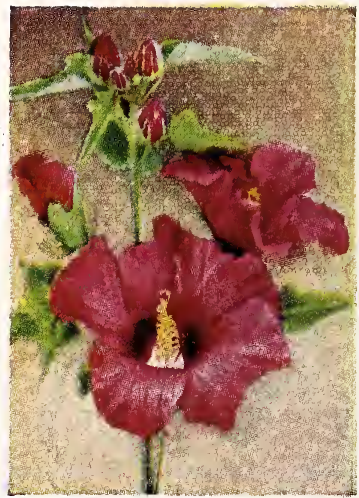

Hibiscus-Mallow Marvel. 
PAPAVER (Hardy Poppies). Both the Iceland and Oriental Poppies are used extensively in the best gardens. The Iceland is excellent for cutting.

P. nudicaule (Iceland Poppy). New Hybrids. Mixed colors; bloom all summer. 18 inches.

P. orientale (Oriental Poppy). Orange-scarlet.

P. orientale, Oriflamme. Large scarlet.

P. orientale, Princess Victoria. Salmon

P. orientale, Hybrids. Mixed. These contain the most beautiful colors imaginable.

PENTSTEMON (Beard Tongue). Most useful showy perennials, flowering throughout the summer months.

P. grandifora. Mixed. Containing a great variety of sorts. 2 to 3 feet

PHLOX. One of the hardiest and longest lived perennials. We have a selection of eight colors, the very cream of the Phloxes. Deep red, rose-pink, salmon, nurple, lavender, nink and white, pure white, and lilac.

P. subulata. Mistlike evergreen foliage, which from April till June is coveref with masses of beautiful blooming colors; lavender and pink. Good for rockery.

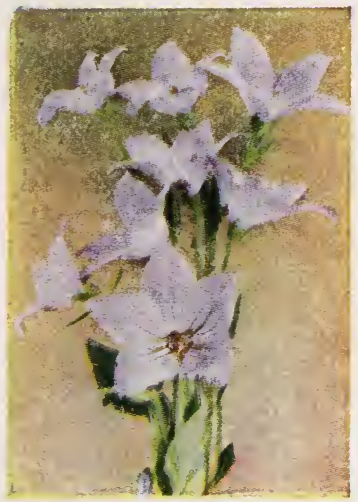

Platycodon-Balloon Flower.

PHYSALIS Francheti (Chinese Lantern Plant). An ornamental variety of the Winter Cherry, forming dense bushes about 2 feet high, producing freely its bright orange-scarlet, lanternlike fruits which can be cut and dried, in which shape they are used extensively for floral decoration during the winter.

PLATYCODON (Japanese Bellflower). One of the best hardy perennials, producing very showy flowers during the whole season. Excellent for planting in permanent borders or among shrubbery.

P. grandiflorum. Large, steel-blue flowers. to 3 feet.

POLYANTHUS, English Mixed. A very good grade saved from a fine strain containing all colors.

PRIMULA japenica (Japanese Primrose). Bright and showy flowers; borne in whorls on stems 6 to 9 inches long. Mixed color's.

P. vulgaris (English Primrose). Canary-yellow; fragrant.

P. veris. Various shades of lilac, purple, violet, as well as a wide range of buff, orange, salmon and rich red. Mixed colors.

PYRETHRUM hybridum (Painted Daisy). One of the really good hardy perennials. Valuable alike for cutting or planting in the hardy border.

P., Single. Mixed colors.

P. grandiflorum. Single, large-flowering mixed.

P., Double. Saved from a fine strain. 2 to 3 feet.

RUDBECKIA (Coneflower). Indispensable plants for the hardy border, grow and thrive anywhere, giving a wealth of bloom; are well suited for cutting.

R. Newmanni. Dark orange-yellow flowers, with deep purple cone, borne on stiff, wiry stems, feet high; flowers from July to September.

R. purpurea (Giant Purple Coneflower). Flowers about 4 inches across, of a peculiar reddish purple with a remarkably large, cone-shaped center of brown; blooms from July to October.

SAPONARIA ocymoides (Soapwort). A very useful hardy plant for the rockery or the border. producing from May to August masses of at producing from May to August masses of at-
tractive, small, bright rose flowers. 8 inches.

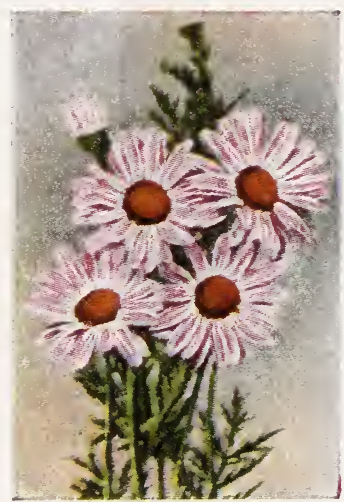

Pyrethrum.

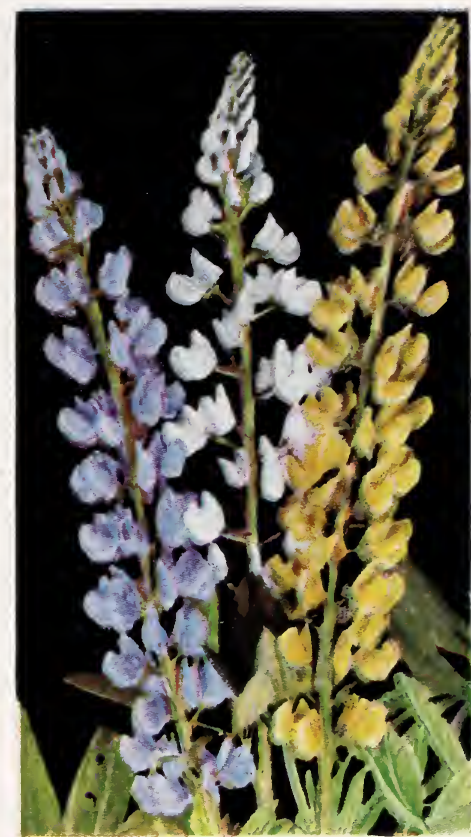

Lupines.

SALVIA farinacea (Sage). Light blue; makes a fine plant for the rockery. 3 feet.

SCABIOSA caucasica (Blue Bonnet) One of the handsomest of hardy perennials, especially valuable for cutting, the blooms lasting a long time in water. Color soft lavender-blue. 3 feet.

SIDALCEA, Rosy Gem. Erect growing, branching plants with mallow-like flowers of beautiful rose color bloom in June and July.

STATICE (Sea Lavender). Splendid hardy perennials, producing all summer panicles of minute flowers, either for the border or the rockery. Can be dried and used for winter bouquets.

S. latifolia. Purplish blue flowers.

STOKESIA (Stokes' Aster). Handsome aster-like flowers; color lavender-blue. One of the best perennials; good for cutting.

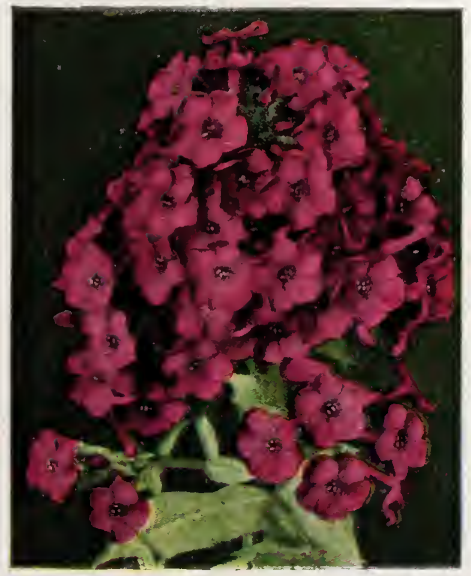

Phlox.
SWEET ROCKET (Hesperis) Oldfashioned hardy garden plants: grow from 2 to 3 feet high and bears spikes of showy white, lilac and purple, fragrant flowers. Excellent for naturalizing among shrubbery or for planting in permanent border. Mixed colors.

SWEET WILLIAM (Dianthus barbatus). There is always a good demand for these beautiful, freeflowering, old-fashioned favorites.

THALICTRUM. One of the real gems among haidy plants, a charming shade of violet which is brightened by a bunch of yellow stamens; bloom in August and September. 4 feet.

TROLLIUS (Globe Flower). Orange-yellow, buttercup-like flowers. Bloom from May to August. 2 feet.

TRITOMA (Red Hot Poker; Flame Flower; or Toreh Lily). Hybrida. Very showy.

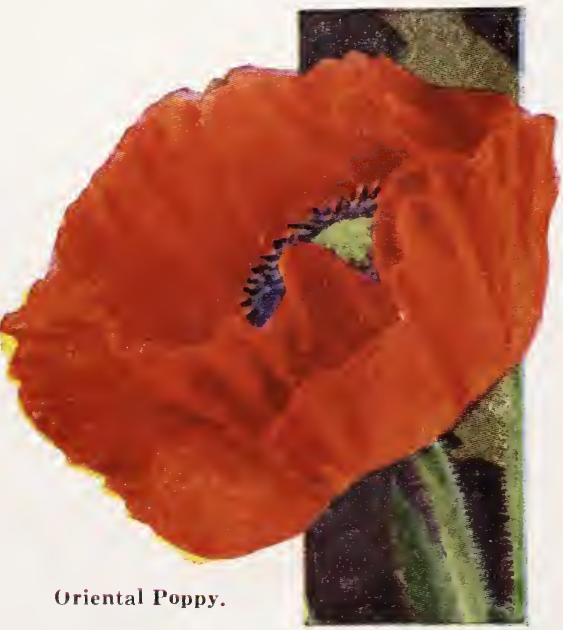




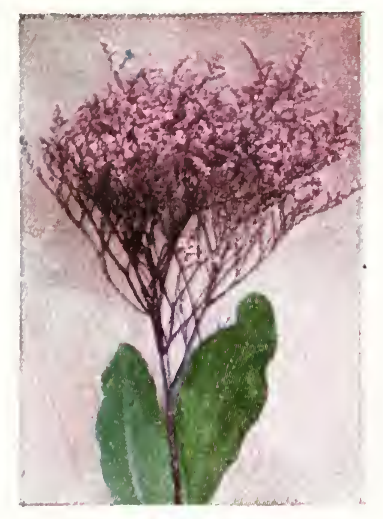

Statice-Great Sea Lavender.

YUCCA (Adam's Needle). A stately perennial with .. swordlike foliage and tall, branched spikes of large, ragrant, drooping, ereamy white flowers during June and July. 6 feet. 5 plants for $\$ 1.10$

\section{PRICE}

All perennials listed, except where noted, \$1.75 per dozen. postpaid. 2-year-old, field-grown clumps, $\$ 3.00$ per dozen clumps. Not less than 2 of a variety at this remarkably low price.

HARDY PERENNIALS-Continued.

VALERIANA rubra (Valerian), Mixed Showy, hardy border plants, producin large corymbs of red or white flowers fine for bouquets. 2 feet.

VERONICA maritima (longiflora). (Speedwell), Long spikes of blue flowers from July to September.

V. spicata. An elegant hardy border plant, crowing about $11 /$ feet high, producing long spikes of bright blue flowers in June and July.

VIOLA, Jersey Gem. The choicest violet blooms from early spring until the ground freezes. Likes shade. 4 plants for $\$ 1.10$.

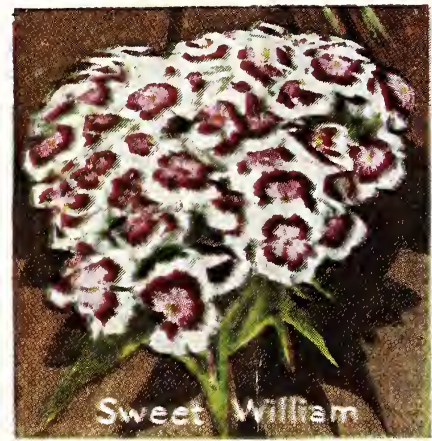

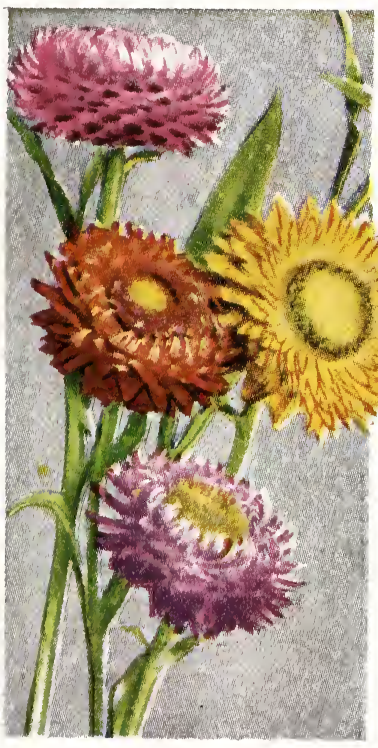

Helichrysum

LARKSPUR. In blue, rosy red, pink, mixed. 25 plants for $\$ 1.10$.

SALVIA farinacea. Blue. Half hardy. 20 plants for \$1.10.

STRAWFLOWERS. In only the good colors, mixed. 40 plants for $\$ 1.10$

ZINNIAS. Dahlia-flowered, in brilliant colors, mixed. 25 plants for $\$ 1.10$.

\section{New Market Perennial Gardens}

New Market, New Jersey $\$ 1.10$.

\section{Annual Flower Plants}

These annuals are mostly grown in until June can

STER, American Beauty. In all the best colors. 40 plants for $\$ 1.10$.

. California Giant. In 6 good color

Chese Asters are an improvement on our regular Asters. Flowers are the size of a large plants. 25 plants for si.10.

SNAPDRAGON NOVELTY. In 18 colors mixed. A

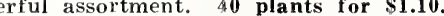
plants for $\$ 1.10$.

CANDYTUFT. In mixed colors, 25 plants for $\$ 1.10$. CHINESE FORGET-ME-NOT. Rich blue; very good for cut flowers. Bloom all summer. 25 plants for

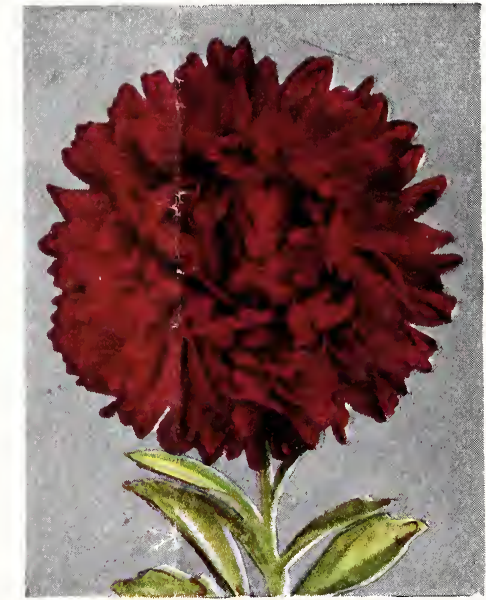

American Beauty Aster.

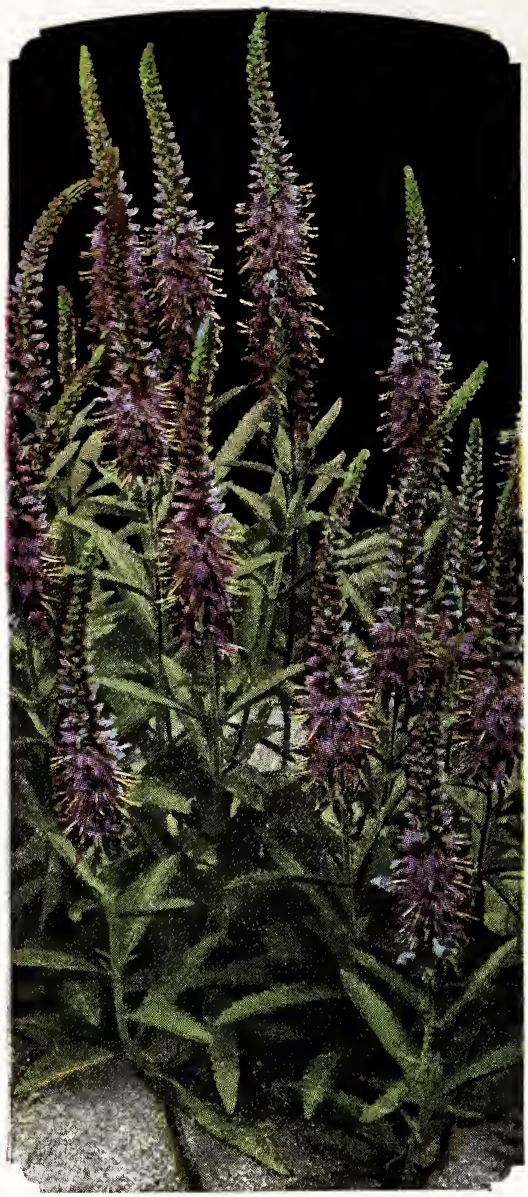

Veronica.

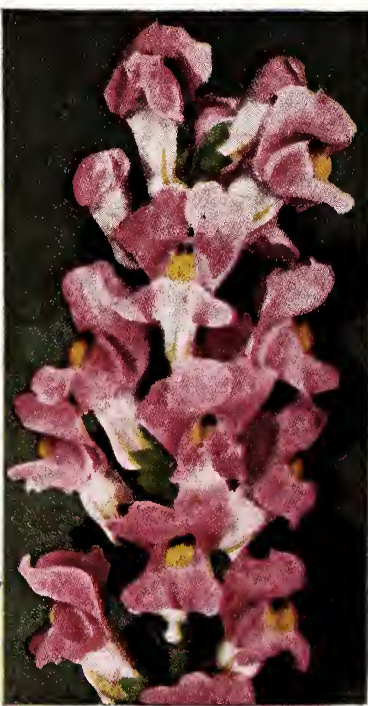

Snapdragon.

We certainly will appreciate every order, large or small, and try to please you. 